\title{
PENGARUH HARAPAN ORANG TUA DAN SELF-EFFICACY AKADEMIK TERHADAP KECENDERUNGAN FEAR OF FAILURE PADA SISWA: ANALISIS PERBANDINGAN ANTARA SISWA KELAS UNGGULAN DAN SISWA KELAS REGULER
}

\author{
Abdul Muhid, Alfiatul Mukarromah \\ Universitas Islam Negeri Sunan Ampel Surabaya \\ E-mail:abdulmuhid@uinsby.ac.id, alfiatulm7@gmail.com
}

\begin{abstract}
This study aims to examine the influence of parent expectation and academic selfefficacy on student's fear of failure tendencies. In addition, this study also aims to examine the average comparison of parent expectation, academic self-efficacy, and student's fear of failure tendencies between students of excellent class program and students of reguler class program. This study uses a quantitative approach with survey methods. The subjects of this study amounted to 271 students, 134 students of excellent class program and 137 students of reguler class program. The results showed that there was a significant influence of parent expectation and academic self-efficacy on student's fear of failure tendencies, howeverthe results showed no significant differences the average comparison of parent expectation, academic self-efficacy, and student's fear of failure tendencies between students of excellent class program and students of reguler class program.
\end{abstract}

Keywords: Parent Expectation, Academic Self-Efficacy, Fear of Failure.

\begin{abstract}
Abstrak
Penelitian ini bertujuan untuk menguji pengaruh harapan orang tua dan selfefficacy akademik terhadap kecenderungan fear of failure pada siswa. Di samping itu, penelitian ini juga bertujuan menguji perbandingan rata-rata harapan orang tua, self-efficacy akademik, dan kecenderungan fear of failure antara siswa kelas unggulan dan siswa kelas regular. Penelitian ini menggunakan pendekatan kuantitatif dengan metode survei. Subyek penelitian ini berjumlah 271 siswa terdiri atas siswa program kelas unggulan sebanyak 134 orang dan siswa program kelas reguler sebanyak 137 orang. Hasil penelitian menunjukkan ada pengaruh yang signifikan antara harapan orang tua dan self-efficacy akademik terhadap kecenderungan fear of failure pada siswa, tetapi tidak ada perbedaan yang signifikan rata-rata harapan orang tua, self-efficacy akademik, dan kecenderungan fear of failure ditinjau antara siswa kelas unggulan dan siswa kelas regular.
\end{abstract}

Kata Kunci: Harapan Orang Tua, Self-Efficacy Akademik, Fear of Failure. 


\section{A. Pendahuluan}

Siswa Sekolah Menengah Atas sangat rentan terhadap kecenderungan perilaku stres belajar. Para siswa dihadapkan pada banyaknyatugas sekolah, waktu belajar yang cukup melelahkan, di samping itu mereka juga harus melaksanakan tugas-tugas perkembangan sebagai seorang remaja. Menurut Desmita (2012), kecenderungan remaja mengalami masa-masa yang penuh dengan stres karena dihadapkan berbagai pekerjaan atau tugas secara bersamaan, mulai dari tugastugas sekolah, beban belajar yang cukup berat, kecemasan dan kebingungan dalam menentukan pilihan karier dan program pendidikan lanjutan, membagi waktu mengerjakan pekerjaan rumah, olahraga, hobi dan kehidupan sosial remaja lainnya.

Selain itu, selama masa sekolah siswa juga dihadapkan pada tuntutan dari orang lain (orang tua dan guru) serta dari diri sendiri untuk selalu berprestasi di sekolah. Banyaknya tuntutan dan harapan orang tua sangat mempengaruhi stress akademik pada siswa (Olejik dan Holschuh, 2007). Maka, untuk merespon tuntutan tersebut siswa sering mengalami kecemasan, merasa tegang dan gelisah sebagai bentuk reaksi perasaan berupa takut gagal atau yang disebut juga dengan fear of failure. Menurut Conroy (2002), fear of failure adalah dorongan untuk menghindari kegagalan terutama konsekuensi negatif kegagalan berupa rasa malu, menurunnya konsep diri individu, dan hilangnya pengaruh sosial. Sedangkan menurut Murray dan Atkinson (dalam Elliot dan Thrash, 2004) fear of failureadalah kecenderungan disposisional motif yang berbasis penghindaran kegagalan, karena seseorang merasa malu terhadap kegagalan.

Hasil penelitian terdahulu menunjukkan ada hubungan positif yang signifikan antara harapan orang tua denganfear of failure (Nainggolan, 2007; Hidayah, 2012; Munauwaroh, 2012). Gintulangi dan Prihastuti (2014) dalam penelitiannya menunjukkan ada hubungan positif yang signifikan antara harapan orangtua dengan tingkat stress mahasiswa dalam penyelesaian studi tingkat sarjana. Berdasarkan temuan penelitan tersebut menunjukkan bahwa fear of failuredapat disebabkan oleh tuntutan dari orang lain, salah satunya adalah orang tua yang pengaruhnya sangat besar pada anak. Artinya, tuntutan orang tua kepada anaknya untuk mencapai prestasi yang tinggi dapat menyababkan anak 
mengalami fear of failure. Tuntutan itu sendiri berasal dari harapan yang dimiliki orang tua supaya anak berhasil dalam bidang akademiknya. Apabila kegagalan ini berlangsung terus menerus, maka lama kelamaan dapat mengakibatkan anak mengalami ketakutan akan kegagalan, kemudian anak akan merespon ketakutan itu dengan cara menjauhi sumber rasa takut. Akhirnya anak akan mendapatkan nilai jelek dan memperoleh prestasi yang jelek pula (Winkel, 1996).

Kenyataannya, seringkali siswa mengalami situasi yang dilematis, siswa dipenuhi pertentangan antara keharusan memenuhi harapan orang tua dengan keterbatasan kemampuan akademiknya. Adanya harapan orang tua yang tinggi, harapan yang tidak realistik terhadap siswa dapat mempengaruhi persepsi siswa terhadap keyakinannya, dan apakah siswa dapat menggapai prestasi yang dikehendaki (Hurlock, 2000). Tuntutan dan harapan orang tua agar anaknya berhasil dalam studi lebih baik dari anak-anak lainnya, dapat dipersepsi secara berbeda oleh para siswa. Pada sebagian siswa, perasaan takut gagal (fear of failure) dapat menjadi cambuk untuk memotivasi dirinya sendiri karena dengan melakukan sesuatu dan hasilnya gagal mereka menganggap bahwa kegagalan itu nyata dan bukan hanya perasaan takut saja, disamping itu adanya dukungan sosial juga dapat meningkatkan motivasi untuk mengatasi rasa takut gagal (Artharini, 2004).

Selain itu, perasaan takut gagal (fear of failure) juga sangat dipengaruhi oleh kadar keyakinan yang dimiliki oleh individu. Keyakinan atau kepercayaan pada kemampuan diri dalam mengatur dan melaksanakan suatu tindakan yang diperlukan dalam rangka pencapaian hasil usaha disebut juga dengan self-efficacy (Bandura, 1997). Self-efficacy mengacu pada persepsi-persepsi seseorang tentang kapabilitasnya untuk menghasilkan tindakan-tindakan. Harapan-harapan atas hasil merupakan keyakinan-keyakinan tentang hasil-hasil yang akan diperoleh dari tindakan-tindakan tersebut (Schunk, 2012). Self-efficacy seseorang cenderung melihat tentang bagaimana cara seseorang mempersepsikan kemampannya mengenai hasil yang akan mereka harapkan.

Menurut causal attribution, siswa yang memiliki self-efficacy tinggi cenderung mengartikan kegagalan sebagai kurangnya usaha yang dilakukan. Sedangkan siswa dengan self-efficacy rendah cenderung mengartikan kegagalan 
disebabkan oleh kemampuannya kurang. Siswa yang memiliki self-efficacy tinggi menganggap kegagalan sebagai akibat dari kurangnya usaha yang keras, pengetahuan, dan keterampilan. Siswa yang ragu akan kemampuannya (selfefficacyrendah) akan menjauhi tugas-tugas yang sulit karena tugas tersebut dipandang sebagai ancaman baginya (Pudjiastuti, 2012).

Berdasarkan hal tersebut, peneliti ingin membuktikan di lapangan apakah ada pengaruh harapan orang tua dan self-efficacy akademik dengan kecenderungan fear of failure pada siswa. Dalam penelitian ini juga mengungkap perbedaan harapan orang tua, self-efficacy akademik, dan kecenderungan fear of failure pada siswa ditinjau dari siswa kelas unggulan dan siswa kelas reguler. Sebab siswa kelas unggulan cenderung memiliki beban tinggi karena ada penambahan materi pelajaran dan kurikulum tersendiri dibanding kelas regular. Siswa kelas unggulan juga lebih tinggi tuntutan sukses secara akademik dibanding siswa kelas reguler, sebab siswa kelas unggulan dituntut untuk dapat mencapai ketuntasan belajar di atas kelas regular (Supriyono, 2009). Penelitian Hanum, dkk. (2016) menunjukkan bahwa siswa kelas unggulan rata-rata lebih tinggi harapan orang tua, keyakinan diri dan stress akademik dibanding dengan kelas reguler. Hal itu menunjukkan bahwa siswa kelas unggulan lebih tinggi tuntutan akan kesuksesan akademik dibandingkan dengan siswa kelas regular.

Penelitian ini mengambil sampel di beberapa sekolah yang menyelenggarakan kelas unggulan pada beberapa SMA di Bojonegoro. Kelas unggulan ini semuanya diselenggarakan pada kelompok kelas IPA, di mana pada kelas IPA ini cenderung menegakkan aturan dan disiplin yang ketat, dan dituntut untuk sukses secara akademik. Penelitian Fitiani (2011) menunjukkan bahwa siswa kelas IPA memiliki tingkat stres yang lebih tinggi dibandingkan dengan siswa kelas IPS. Karena mata pelajaran di kelas IPA terdiri dari Matematika, Fisika dan Kimia yang mengharuskan untuk berfikir secara logis. Oleh karena itu, dalam penelitian ini juga dianalisis perbandingan harapan orang tua, self-efficacy akademik, dan kecenderungan fear of failure antara siswa kelas unggulan dan siswa kelas reguler. Berdasarkan latar belakang masalah tersebut, maka masalah penelitian ini dirumuskan sebagai berikut: 1) Apakah ada pengaruh antara harapan orang tua terhadap kecenderungan fear of failure pada siswa? 2) Apakah ada 
pengaruh antara self-efficacy akademik terhadap kecenderungan fear of failure pada siswa? 3) Apakah ada pengaruh secara bersama-sama antara harapan orang tua dan self-efficacy akademik terhadap kecenderungan fear of failure pada siswa? 4) Apakah ada perbedaan harapan orang tua, self-efficacy akademik, dan kecenderungan fear of failureditinjau dari siswa program kelas unggulan dan siswa pogram kelas reguler?

\section{B. Landasan Teori}

Istilah fear of failure dalam kajian di bidang psikologi dapat ditemukan dalam teori motivasi berprestasi (achievement motivation theory) dan teori kebutuhan berprestasi (need achievement theory) dari Atkinson (Atkinson, dalam Nelson, Newman, McDaniel dan Buboltz, 2013). Fear of failure secara konseptual menurut teori motivasi berprestasi (achievement motivation theory) adalah sebuah motivasi yang menjauhkan seseorang untuk mencapai kesuksesan, sehingga mengalami pengalaman malu atau mendapatkan penghinaan sebagai konsekuensi dari kegagalan (Chua dan Bedford, 2016). Fear of failure adalah suatu perasaan yang disertai perasaan gelisah dan tegang yang dihadapi oleh siswa, dimana terdapat suatu tekanan secara terus-menerus baik dari orang lain maupun diri sendiri untuk mendapatkan prestasi yang baik (Winkel, 2009). Elison, dkk (2012) mendefinisikan fear of failure sebagai disposisi untuk menghindari kegagalan atau menghindari rasa malu atau penghinaan yang merupakan konsekuensi dari kegagalan.

Beberapa teori menyebutkan bahwa faktor-faktor yang melatarbelakangi fear of failure pada siswa yaitu antara lain: (1) suasana belajar mengajar di kelas; (2) suasana dalam keluarga; dan (3) alam pikiran siswa itu sendiri (Winkel, 1996). Sedangkan menurut Asmadi (dalam Nainggolan, 2007) ada 3 (tiga) hal yang mempengaruhi perasaan fear of failure adalah sebagai berikut: (1) kurangnya rasa percaya diri; (2) ketidakmampuan mengahadapi kompetisi; dan (3) harapan orang tua yang terlalu tinggi. Adapun menurt Conroy (2002) menyatakan bahwa fear of failure disebabkan oleh pengalaman di awal masa kanak-kanak, karakteristik lingkungan, pengalaman belajar, dan karena faktor subjektif dan kontekstual. 
Konsep fear of failure di dunia pendidikan yang berorientasi pada kesuksesan seringkali berdampak pada kecenderungan stres dan depresi di kalangan siswa. Tekanan dari orang tua dan guru untuk selalu sukses di sekolah, harapan siswa untuk selalu mendapatkan hasil belajar yang baik, dan mendapatkan pekerjaan yang sangat baik dan menghasilkan uang banyak adalah suatu hal yang sangat berpengaruh pada sebagian siswa (Santrock, 2008). Kegagalan dalam tugas tertentu akan menimbulkan perasaan rasa takut gagal. Perasaan tersebut sering dialami pelajar dalam situasi kompetitif dan dirasakan kemungkinan untuk gagal. Dorongan menghindari kegagalan merupakan konsekuensi negatif dari fear of failure dan merupakan kapasitas individu untuk mengantisipasi rasa malu dan penghinaan (Atkinson, 1993). Siswa yang mengalami takut gagal (fear of failure) cenderung menghindari situasi yang kompetitif dan beresiko selama belajar. Ketidakpastian akan hal yang akan datang merupakan faktor utama dalam situasi beresiko yang tidak bisa ditoleransi oleh seorang siswa. Situasi yang kompetitif juga dihindari karena apabila siswa gagal menjadi pemenang atau tidak sukses, keyakinan diri maupun keyakinan orang lain terhadap kemampuannya akan menurun, kondisi tersebut berakibat menurunkan motivasi individu dalam mencapai suatu kesuksesan (Petri dalam Dayakisai dan Hudaniah, 2003).

Dampak dari perasaan fear of failure bagi siswa berimplikasi dalam berperilaku belajar seperti pilihan tugas, usaha yang telah dilakukan, kegigihan, pencapaian performansi, motivasi intrinsik dan kesejahteraan. Keadaan tersebut secara tidak langsung mempercepat dan mempengaruhi pengambilan keputusan, strategi penghindaran secara spesifik, misalnya penghindaran performansi yang akhirnya secara langsung mendesak dan menimbulkan pertentangan antara ingin menghindari fear of failure atau mencapai kesuksesan maupun harapan akan sukses (hope of succes) Elliot dan Sheldon (1997).

Perasaan takut gagal (fear of failure) tersebut muncul sebagai hasil ketidakmampuan siswa dalam menghadapi tuntutan akademik yang harus diperoleh, sedangkan siswa harus dapat melewati kehidupan yang semakin berat ini dengan memuaskan harapan orang lain dan dirinya sendiri. Akibat ketidakmampuan siswa menghadapai keadaan yang dilewati antara harapan orang 
tua dan ketidakmampuannya, maka siswa akan melakukan tindakan defensif atau pertahanan diri (Freud dalam Atkinson, 1993).

Menurut Pudjiastuti (2012) bahwa semakin tinggi self-efficacy yang dipersepsi, semakin tinggi goal yang menantang ditentukan untuk dirinya dan semakin kuat komitmen yang dimiliki terhadap goal tersebut. Mereka yang memiliki self-efficacy tinggi akan membayangkan suasana keberhasilan yang menyertainya dalam setiap usaha pencapaian tujuannya. Sebaliknya mereka yang memiliki self-efficacy rendah akan membayangkan terjadinya suasana kegagalan yang menyertainya dalam usaha mencapai tujuan. Penelitian Harmaini dan Hidayat (2012) juga membuktikan bahwa faktor yang mempengaruhi kecenderungan fear of failure adalah faktor internal yaitu self-efficacy siswa. Sedangkan hasil penelitian Wennberg, Pathak, dan Autio, (2013) membuktikan bahwa ada hubungan negatif yang signifikan antara self-efficacy dengan kecenderungan fear of failure.

Berdasarkan landasan teori tersebut di atas, maka dapat disimpulkan bahwa ada hubungan positif antara harapan orang tua dengan kecenderungan fear of failure pada siswa, artinya semakin tinggi harapan orang tua maka semakin tinggi pula kecenderungan fear of failure pada siswa. Sebaliknya, ada hubungan negatif antara self-efficacy akademik dengan kecenderungan fear of failure pada siswa, semakin siswa yang memiliki self-efficacy akademik tinggi maka semakin rendah kecenderungan fear of failure pada siswa. Maka hipotesis yang diajukan dalam penelitian ini adalah sebagai berikut: 1) Ada pengaruh antara harapan orang tua terhadap kecenderungan fear of failure pada siswa. 2) Ada pengaruh antara self-efficacy akademik terhadap kecenderungan fear of failure pada siswa. 3) Ada pengaruh secara bersama-sama antara harapan orang tua dan self-efficacy akademik terhadap kecenderungan fear of failure pada siswa. 4) Ada perbedaan harapan orang tua, self-efficacy akademik, dan kecenderungan fear of failure ditinjau dari siswa program kelas unggulan dan siswa pogram kelas reguler.

\section{Metode Penelitian}

Penelitian ini menggunakan pendekatan kuantitatif dengan metode survei. Subyek penelitian ini berjumlah 271 dari 4 (empat) Sekolah Menengah Atas 
(SMA) di Kabupaten Bojonegoro terpilih (purposive) yang memiliki program kelas unggulan. Dengan menggunakan teknik cluster random sampling pada tiap sekolah terpilih, subyek penelitian ditetapkan secara acak (random) yang terdiri atas 2 (dua) kelompok subyek yaitu siswa program kelas unggulan sebanyak 134 orang dan siswa program kelas reguler sebanyak 137 orang. Teknik pengumpulan data dalam penelitian ini menggunakan 3 (tiga) instrumen penelitian yaitu:

1. Skala Fear of Failure (SFF); digunakan untuk mengukur kecenderungan fear of failure pada siswa berdasarkan teori Conroy (2002:45) yang terdiri atas 5 (lima) aspek yaitu: takut merasa hina dan malu, takut turun estimasi diri, takut hilang pengaruh sosial, takut akan ketidakpastian masa depan,dan takut mengecewakan orang yang penting bagi siswa (orang tua dan guru).

2. Skala Harapan Orang Tua (SHOT); digunakan untuk mengukur harapan orang tua tentang kesuksesan akademik siswa. Instrumen ini disusun berdasarkan aspek-aspek harapan orang tua menurut Sasikala dan Karunanidhi (2011:5) terdiri atas 4 (empat) aspek yaitu: harapan pribadi, harapan akademik, harapan karir, dan ambisi orang tua.

3. Academic Self-efficacy Scale (ASES); digunakan untuk mengukur self-efficacy akademik siswa. Instrumen ini dikembangkan dan dimodifikasi berdasarkan Academic Self-efficacy Scale (ASES) yang telah dikembangkan oleh Gafoor dan Ashraf (2006) yang terdiri atas 12 (dua belas) self-efficacy di bidang: proses pembelajaran, membaca, pemahaman, memori, aktifitas kurikuler, managemen waktu, hubungan guru-siswa, pemanfaatan sumber daya, hubungan teman sebaya, orientasi tujuan, penyesuaian, dan ujian/tes.

Penelitian ini menguji 4 (empat) hipotesis, yaitu: (1) ada pengaruh antara harapan orang tua terhadap kecenderungan fear of failure pada siswa; (2) ada pengaruh antara self-efficacy akademik terhadap kecenderungan fear of failure pada siswa; (3) ada pengaruh secara bersama-sama antara harapan orang tua dan self-efficacy akademik terhadap kecenderungan fear of failure pada siswa; dan (4) ada perbedaan harapan orang tua, self-efficacy akademik, dan kecenderungan fear of failure ditinjau dari siswa program kelas unggulan dan siswa pogram kelas reguler.Untuk menguji hipotesis penelitian nomer 1, 2, dan 3 digunakan uji Analisis Regresi Ganda (ANAREG) dengan bantuan Program SPSS for Wondows 
Versi 16. Sedangkan untuk menguji hipotesis nomer 4 menggunakan Analisis Varian (ANOVA) Satu Arah dengan bantuan Program SPSS for Wondows Versi 16.

\section{Hasil Penelitian}

Berdasarkan analisis uji korelasi Product Moment dari Pearson sebagaimana pada Tabel. 1 Uji Korelasi menunjukkan hasil sebagai berikut:

1. Hubungan antara harapan orang tua dengan kecenderungan fear of failurepada siswa menunjukkan harga koefisien korelasi = 0,173 dengan sig. $=0,002<0,05$ artinya ada hubungan positif yang signifikan antara harapan orang tua dengan kecenderungan fear of failure pada siswa. Berdasarkan hal tersebut maka dapat dipahami bahwa semakin tinggi harapan orang tua terhadap kesuksesan akademik siswa maka semakin tinggi kecenderungan fear of failure pada siswa, dan sebaliknya.

2. Hubungan antara self-efficacy akademik dengan kecenderungan fear of failure pada siswa menunjukkan harga koefisien korelasi = -0,198 dengan sig. $=0,001<0,05$ artinya ada hubungan negatif yang signifikan antara selfefficacy akademik dengan kecenderungan fear of failure pada siswa. Berdasarkan hal tersebut maka dapat dipahami bahwa semakin tinggi selfefficacy akademik siswa maka semakin rendah kecenderungan fear of failure pada siswa, dan sebaliknya.

Tabel. 1 Uji Korelasi

\begin{tabular}{|c|c|c|c|c|}
\hline \multicolumn{5}{|c|}{ Correlations } \\
\hline & & \begin{tabular}{l|} 
Fear of \\
Failure
\end{tabular} & $\begin{array}{c}\text { Parents } \\
\text { Expectation }\end{array}$ & $\begin{array}{c}\text { Academic Self- } \\
\text { Efficacy }\end{array}$ \\
\hline \multirow{3}{*}{$\begin{array}{l}\text { Pearson } \\
\text { Correlation }\end{array}$} & Fear of Failure & 1.000 & .173 & -.198 \\
\hline & Parents Expectation & .173 & 1.000 & .183 \\
\hline & Academic Self-Efficacy & -.198 & .183 & 1.000 \\
\hline \multirow[t]{3}{*}{ Sig. (1-tailed) } & Fear of Failure & . & .002 & .001 \\
\hline & Parents Expectation & .002 & & .001 \\
\hline & Academic Self-Efficacy & .001 & .001 & \\
\hline \multirow[t]{3}{*}{$\mathrm{N}$} & Fear of Failure & 271 & 271 & 271 \\
\hline & Parents Expectation & 271 & 271 & 271 \\
\hline & Academic Self-Efficacy & 271 & 271 & 271 \\
\hline
\end{tabular}

Sumber. Data Lapangan di Olah. 2018 
Berdasarkan hasil analisis uji regresi ganda sebagaimana pada Tabel 2. Uji Pengaruh Model Summary menunjukkan harga $\mathrm{R}=0,291$ dengan $\mathrm{R}$ Square = 0,085 menunjukkan pengaruh secara bersama-sama variabel prediktor harapan orang tua dan self-efficacy akademik terhadap variabel kriterium (dependen) kecenderungan fear of failure yaitu sebesar 8,5\%.Pada Tabel. 3 ANOVA menunjukkan harga $F=12,411$ dengan Sig. $0,000<0,05$ artinya ada pengaruh yang signifikan antara harapan orang tua dan dan self-efficacy akademik terhadap kecenderungan fear of failure pada siswa. Berdasarkan hal tersebut, hipotesisyang diajukan bahwa ada pengaruh secara bersama-sama antara harapan orang tua dan self-efficacy akademik terhadap kecenderungan fear of failure pada siswa diterima.

Tabel. 2 Uji Pengaruh Bersama-Sama

\begin{tabular}{|l|r|r|r|c|}
\hline \multicolumn{5}{|c|}{ Model Summary $^{\mathbf{b}}$} \\
\hline Model & $\mathrm{R}$ & R Square & $\begin{array}{c}\text { Adjusted R } \\
\text { Square }\end{array}$ & $\begin{array}{c}\text { Std. Error of the } \\
\text { Estimate }\end{array}$ \\
\hline 1 & $.291^{\mathrm{a}}$ & .085 & .078 & 12.66470 \\
\hline
\end{tabular}

a. Predictors: (Constant), Academic Self-Efficacy, Parents Expectation

b. Dependent Variable: Fear of Failure

Sumber. Data Lapangan di Olah. 2018

Tabel. 3 ANOVA

\begin{tabular}{|l|l|r|r|r|r|r|}
\hline \multicolumn{7}{|c|}{ ANOVA $^{\mathbf{b}}$} \\
\hline \multirow{2}{*}{ Model } & Sum of Squares & Df & Mean Square & \multicolumn{1}{c|}{ F } & Sig. \\
\hline & Regression & 3981.271 & 2 & 1990.635 & 12.411 & $.000^{\mathrm{a}}$ \\
\cline { 2 - 8 } & Residual & 42985.784 & 268 & 160.395 & & \\
\cline { 2 - 8 } & Total & 46967.055 & 270 & & & \\
\hline
\end{tabular}

a. Predictors: (Constant), Academic Self-Efficacy, Parents Expectation

b. Dependent Variable: Fear of Failure

Sumber. Data Lapangan di Olah. 2018

Tabel. 4 Uji Pengaruh Parsial

\begin{tabular}{|c|c|c|c|c|c|c|}
\hline \multicolumn{7}{|c|}{ Coefficients $^{\mathrm{a}}$} \\
\hline & & \multicolumn{2}{|c|}{ Unstandardized Coefficients } & \multirow{2}{*}{$\begin{array}{c}\text { Standardized } \\
\text { Coefficients } \\
\text { Beta }\end{array}$} & \multirow[b]{2}{*}{$\mathrm{T}$} & \multirow[b]{2}{*}{ Sig. } \\
\hline \multicolumn{2}{|c|}{ Model } & B & Std. Error & & & \\
\hline \multirow[t]{3}{*}{1} & (Constant) & 69.758 & 9.570 & & 7.290 & .000 \\
\hline & Parents Expectation & .312 & .086 & .217 & 3.646 & .000 \\
\hline & $\begin{array}{l}\text { Academic Self- } \\
\text { Efficacy }\end{array}$ & -.319 & .080 & -.238 & -4.004 & .000 \\
\hline
\end{tabular}

a. Dependent Variable: Fear of Failure

Sumber. Data Lapangan di Olah. 2018 
Berdasarkan Tabel. 4 Uji Pengaruh Parsial Coefficients menunjukkan hasil sebagai berikut:

1. Pengaruh harapan orang tua terhadap terhadap kecenderungan fear of failure pada siswa menunjukkan harga Standarized Coefficients Beta $=0,217$, dengan harga $\mathrm{t}=3,646$ dengan Sig. $=0,000<0,05$ artinya ada pengaruh yang signifikan antara harapan orang tua terhadap terhadap kecenderungan fear of failure pada siswa. Berdasarkan hal tersebut maka hipotesis yang menyatakan ada pengaruh antara harapan orang tua terhadap terhadap kecenderungan fear of failure pada siswa, diterima.

2. Pengaruh self-efficacy akademik terhadap kecenderungan fear of failure pada siswa menunjukkan harga Standarized Coefficients Beta $=-0,238$, dengan harga $\mathrm{t}=-4,004$ dengan Sig. $=0,000<0,05$ artinya ada pengaruh yang signifikan antara self-efficacy akademik terhadap kecenderungan fear of failure pada siswa, berdasarkan hal tersebut maka hipotesis yang menyatakan ada pengaruh antara self-efficacy akademik terhadap terhadap kecenderungan fear of failure pada siswa, diterima.

Tabel. 5 Uji Perbandingan Harapan Orang Tua

\begin{tabular}{|c|c|c|c|c|c|}
\hline \multicolumn{6}{|c|}{ ANOVA } \\
\hline \multicolumn{6}{|c|}{ Parents Expectation } \\
\hline & Sum of Squares & df & Mean Square & $\mathrm{F}$ & Sig. \\
\hline Between Groups & 2.264 & 1 & 2.264 & .027 & .870 \\
\hline Within Groups & 22639.109 & 269 & 84.160 & & \\
\hline Total & 22641.373 & 270 & & & \\
\hline
\end{tabular}

Sumber. Data Lapangan di Olah. 2018

Berdasarkan hasil uji perbandingan rata-rata harapan orang tua tentang kesuksesan akademik siswa antara siswa kelas unggulan dan siswa kelas reguler menunjukkan harga $\mathrm{F}=0,027$ dengan $\mathrm{Sig} .=0,870>0,05$ artinya tidak ada perbedaan yang signifikan rata-rata harapan orang tua tentang kesuksesan akademik siswa antara siswa kelas unggulan dan siswa kelas reguler. Hal itu berarti hipotesis yang menyatakan ada perbedaan rata-rata harapan orang tua tentang kesuksesan akademik siswa antara siswa kelas unggulan dan siswa kelas reguler, ditolak. 
Tabel. 6 Uji Perbandingan Self-Efficacy Akademik

\begin{tabular}{|l|r|r|r|r|r|}
\hline \multicolumn{7}{|c|}{ ANOVA } & & \\
\hline Academic Self-Efficacy & \multicolumn{1}{|c|}{ df } & Mean Square & \multicolumn{1}{c|}{ F } & \multicolumn{1}{c|}{ Sig. } \\
\hline & Sum of Squares & \multicolumn{1}{|c|}{ df } & 18.819 & .194 & .660 \\
\hline Between Groups & 18.819 & 1 & 96.934 & & \\
\hline Within Groups & 26075.129 & 269 & & & \\
\hline Total & 26093.948 & 270 & & \\
\hline
\end{tabular}

Sumber. Data Lapangan di Olah. 2018

Berdasarkan hasil uji perbandingan rata-rata self-efficacy akademik antara siswa kelas unggulan dan siswa kelas reguler menunjukkan harga $\mathrm{F}=$ 0,194 dengan Sig. = 0,660>0,05 artinya tidak ada perbedaan yang signifikan rata-rata self-efficacy akademik antara siswa kelas unggulan dan siswa kelas reguler. Hal itu berarti hipotesis yang menyatakan ada perbedaan rata-rata self-efficacy akademik antara siswa kelas unggulan dan siswa kelas reguler, ditolak.

Tabel. 7 Uji Perbandingan Fear of Failure

\begin{tabular}{|l|r|r|r|r|r|}
\hline \multicolumn{2}{|c|}{ ANOVA } & \\
\hline \multirow{2}{*}{ Fear of Failure } & & & & & \multicolumn{1}{c|}{ Sig. } \\
\cline { 2 - 7 } & Sum of Squares & \multicolumn{1}{|c|}{ df } & Mean Square & F & .986 \\
\hline Between Groups & .054 & 1 & .054 & .000 & \\
\hline Within Groups & 46967.001 & 269 & 174.599 & & \\
\hline Total & 46967.055 & 270 & & & \\
\hline
\end{tabular}

Sumber. Data Lapangan di Olah. 2018

Berdasarkan hasil uji perbandingan rata-rata kecenderungan fear of failure antara siswa kelas unggulan dan siswa kelas reguler menunjukkan harga $\mathrm{F}=0,194$ dengan Sig. $=0,660>0,05$ artinya tidak ada perbedaan yang signifikan rata-rata kecenderungan fear of failure antara siswa kelas unggulan dan siswa kelas reguler. Hal itu berarti hipotesis yang menyatakan ada perbedaan rata-rata kecenderungan fear of failure antara siswa kelas unggulan dan siswa kelas reguler, ditolak.

\section{E. Pembahasan}

Penelitian ini secara umum menunjukkan bahwa ada pengaruh yang signifikan baik secara bersama-sama maupun secara parsial antara harapan orang tua dan self-efficacy akademik terhadap kecenderungan fear of failure pada siswa. Hal itu menunjukkan bahwa variabel harapan orang tua dan self-efficacy 
akademik secara nyata dapat dijadikan variabel prediktor yang mempengaruhi kecenderungan fear of failure pada siswa. Artinya, tinggi rendahnya kecenderungan fear of failure siswa dapat dijelaskan seberapa besar tinggi rendahnya harapan orang tua dan self-efficacy akademik siswa.

Penelitian ini membuktikan bahwa ada hubungan positif yang signifikan antara harapan orang tua dengan kecenderungan fear of failure pada siswa, artinya semakin tinggi harapan orang tua terhadap kesuksesan akademik siswa semakin tinggi pula kecenderungan fear of failure siswa, dan sebaliknya. Penelitian ini menguatkan kembali temuan penelitian sebelumnya yang mengatakan bahwa semakin tinggi harapan orang tua yang dipersepsi maka semakin tinggi pula fear of failure (Hidayah, 2012). Temuan tersebut menguatkan teori-teori yang telah ada bahwa tuntutan dan harapan orang tua yang tinggi terhadap keberhasilan akademik sangat mempengaruhi kecederungan takut gagal (fear of failure) pada siswa. Tuntutan dan harapan orang tua terhadap keberhasilan akademik siswa berdampak pada perasaan takut, putus asa, cemas, dihinggapi perasaan malu dan rasa khawatir jika siswa tersebut tidak dapat meraih apa yang diharapkan orang tua. Siswa yang merasa takut gagal cenderung tidak berani melakukan tugas-tugas akademik, karena jika mengalami kegagalan dan tidak sesuai dengan harapan orang tua siswa takut dimarahi dan takut kehilangan kasih sanyang orang tua (Kartono, 1990).

Harapan orang tua yang tinggi terhadap keberhasilan akademik anaknya mendorong orang tua untuk menekankan prestasi akademik sebagai wujud ketundukan anak terhadap orang tuanya. Hal ini kemudian dapat memunculkan perasaan tertekan pada diri anak dan dapat menimbulkan rasa cemas jika anak tidak dapat mewujudkan apa yang diharapkan oleh orang tuanya. Penelitian Permatasari dkk. (2018) menunjukkan bahwa harapan orang tua yang tinggi dapat menjadi ancaman dan memperbesar kecemasan siswa. Orang tua yang tidak realistis dalam menginginkan keberhasilan siswa dapat membuat siswa tersebut cenderung cemas dan merasa takut jika tidak berhasil secara akademik.

Di samping itu, penelitian ini juga membuktikan bahwa ada hubungan negatif yang signifikan antara self-efficacy akademik terhadap kecenderungan fear of failure pada siswa. Artinya, semakin tinggi self-efficacy akademik siswa maka 
semakin rendah kecenderungan fear of failure pada siswa, dan sebaliknya. Hal itu menguatkan temuan penelitian sebelumnya bahwa faktor-faktor yang mempengaruhi kecenderungan fear of failure adalah kepercayaan diri atas kemampuan yang dimiliki individu (Rondha dan Christianingrum, 2013). Hal itu karena self-efficacy merupakan persepsi tentang kemampuan yang dimiliki seseorang sebagai modal untuk melakukan suatu tugas tertentu. Bandura (dalam Baron dan Byrne, 2004) menyatakan bahwa self-efficacy adalah evaluasi seseorang terhadap kemampuan untuk melakukan sebuah tugas, mencapai tujuan, atau mengatasi hambatan. Sedangkan menurut Feist dan Feist (2006) self-efficacy adalah keyakinan atas kesanggupan untuk melakukan tugas tertentu. Berdasarkan ini dapat dijelaskan bahwa seseorang yang memiliki self-efficacy akademik tinggi maka seseorang memiliki estimasi terhadap keberhasilan, sehingga yakin dan mampu melakukan suatu tugas akademik dengan optimal. Sebaliknya jika seseorang itu memiliki self-efficacy akademik yang rendah maka seseorang cenderung cemas jika tidak berhasil dan takut untuk melakukan suatu tugas akademik, karena dibayang-bayangi kegagalan dan ketidak berhasilan dalam akademik.

Kesuksesan dan kegagalan seseorang sangat dipengaruhi oleh sejauhmana self-efficacy seseorang. Temuan Yilmiz (2018) menunjukkan bahwa ada hubungan negatif yang signifikan antara self-efficacy dengan fear of success. Hal itu menguatkan penelitian Ayazi dkk. (2013) yang menunjukkan bahwa selfefficacy sangat mempengaruhi fear of success. Variabel self-efficacy sebagai variabel prediktor memprediksi kecenderungan fear of success. Berdasarkan hal tersebut, kesuksesan dan kegagalan seseorang sangat tergantung dari self-efficacy. Semakin tinggi self-efficacy yang dipersepsi seseorang, semakin kuat komitmen seseorang untuk meraih keberhasilan. Mereka yang memiliki self-efficacy tinggi akan membayangkan suasana keberhasilan (succsess) yang menyertainya dalam setiap usaha pencapaian tujuannya. Sebaliknya mereka yang memiliki selfefficacy rendah akan membayangkan terjadinya suasana kegagalan (failure) yang menyertainya dalam usaha mencapai tujuan (Pudjiastuti, 2012).

Siswa yang memiliki self-efficacy tinggi cenderung mengartikan kegagalan (failure) sebagai kurangnya usaha yang dilakukan. Sedangkan individu 
dengan self-efficacy rendah cenderung mengartikan kegagalan disebabkan oleh kemampuannya kurang. Individu yang memiliki self-efficacy tinggi menganggap kegagalan sebagai akibat dari kurangnya usaha yang keras, pengetahuan, dan keterampilan. Individu dengan self-efficacy rendahakan menjauhi tugas-tugas yang sulit karena tugas tersebut dipandang sebagai ancaman baginya (Pudjiastuti, 2012). Siswa yang memilikiself-efficacyakademik tinggi berdampak pada rendahnya kecenderungan fear of failure.

Seseorang yang memiliki self-efficacy rendah akan cenderung merasa helpless, tidak mampu melakukan pengaturan pada keadaan yang terjadi dalam hidupnya. Pada saat mereka menghadapi hambatan, mereka mudah menyerah. Seseorang yang memiliki self-efficacy rendah cenderung tidak akan melakukan usaha apapun untuk mengatasi hambatan yang ada, karena mereka percaya bahwa tindakan yang mereka lakukan tidak akan membawa pengaruh apapun. Self efficacy yang rendah dapat merusak motivasi, menurunkan aspirasi, mengganggu kemampuan kognitif, dan mempengaruhi kesehatan fisik (Schultz dan Schultz, 2005).

Dengan penjelasan tersebut di atas, maka dapat dijelaskan bahwa temuan penelitian ini membuktikan kembali secara teoritis variabel harapan orang tua dan self-efficacy akademik masih efektif dapat memprediksi kecenderungan fear of failure pada siswa. Meskipun dalam penelitian ini tidak membuktikan bahwa ada perbedaan harapan orang tua, self-efficacy akademik, dan kecenderungan fear of failure ditinjau dari siswa program kelas unggulan dan siswa pogram kelas regular. Namun, bagaimana pun hasil penelitian ini dapat dijadikan rujukan terutama para siswa agar menjadikan harapan orang tua sebagai motivasi untuk mendapat prestasi akademik yang tinggi, memotivasi untuk meraih keberhasilan dalam bidang akademik sehingga tidak merasa takut gagal (fear of failure), dan menumbuhkan rasa keyakinan pada diri untuk menghadapi tugas-tugas akademik di sekolah.

\section{F. Kesimpulan}

Berdasarkan hasil penelitian tersebut dapat disimpulkan sebagai berikut: 1) ada pengaruh yang signifikan antara harapan orang tua terhadap kecenderungan 
fear of failure pada siswa; 2) ada pengaruh yang signifikan antara self-efficacy akademik terhadap kecenderungan fear of failure pada siswa; 3) ada pengaruh secara bersama-sama antara harapan orang tua dan self-efficacy akademik terhadap kecenderungan fear of failure pada siswa; dan 4) tidak ada perbedaan harapan orang tua, self-efficacy akademik, dan kecenderungan fear of failure ditinjau dari siswa program kelas unggulan dan siswa pogram kelas reguler.

\section{Daftar Pustaka}

Artharini, I. 2004. Kapan Sih Gagal Itu Bisa Disebut Gagal. Dalam www/http://kapan-sihgagal-itu-bisa-disebut-gagal.html (Tue, 12 May 2005).

Atkinson. 1993. Pengantar Psikologi Edisi Ke-8 Jilid Dua (diterjemahkan oleh Nurdjah Taufik \& Agus Dharma). Jakarta: Erlangga.

Ayazi, M., Divkan, B., Shahbazi, M.,and Afsha, L. 2013. Predicted of fear of success from self-efficacy among professional athletes (swimming, gymnastic \& track and field): Islamic azad university Roudehen branch. European Journal of Experimental Biology, 3(3):328-332.

Bandura, A. 1997. Self Efficacy the Exercise of Control. New York: W.H Freeman and Company.

Baron, R.A. \&Byrne, D. 2004. Psikologi Sosial Jilid 1. Jakarta: Penerbit Erlangga.

Chua, H. S., \& Bedford, O. 2016. A Qualitative Exploration of Fear of Failure and Entrepreneurial Intent in Singapore, 43(4), 319-334.

Conroy, D. E., Kaye, M. P., \& Fifer, A. M. 2007. Cognitive Links Between Fear Of Failure And Perfectionism. Journal ofRational-Emotive \& CognitiveBehavior Therapy, 25, 237-253.

Conroy, D. E., Metzler, J. N., \& Hofer, S. M. 2003. Factorial Invariance and Latent Mean Stability of Performance FailureAppraisal Inventory. Structural Equation Modeling, 10, 401-422.

Conroy, D. E., Poczwardowski, A. \& Henschen, K. P. 2001 Evaluative Criteria And Consequences Associated With Failure And Success For Elite Athletes And Performing Artists. Journal of applied sport psychology. Vol 133

Conroy, D.E. 2002. Representational Models Associated With Fear of Failure in Adolencents and Young Adults. Journal of PersonalityVol. 71.5

Dayakisni, T \& Hudaniah. 2003. Psikologi Sosial Edisi Revisi. Malang: UMM Press.

De Castella, K., Byrne, D., \& Covington, M. 2013. Unmotivated or motivated to fail? A cross-cultural study of achievement motivation, fear of failure, and student disengagement. Journal of Educational Psychology, 105(3), 861880. https://doi.org/10.1037/a0032464

Desmita. 2012. Psikologi Perkembangan Peserta Didik. PT Remaja Rosdakarya: Bandung. 
Elison, J \& Patridge, J.A. 2012. Relationship between shame- coping, fear of failure, and perfectionism in college athletes. Journal of Sport Hebavior; 35 (1), 19.

Elliot, J A \& Sheldon, M K. 1997. Avoidance Achivement Motivation: A Personal Goals Analysis. Journal of Personality and Social Psychology. (73)1, 171-185

Elliot, J A \& Thrash, T M. 2004. The Intergrational Transmission of Fear of Failure. Personality and Social Psychology Buletin. (30) 8, 957-971

Feist, J. \& Feist, G.J. 2006. Theories of Personality.ed. VI. Yogyakarta: Pustaka Pelajar.

Fitiani, M. A. 2011. Perbedaan Tingkat Stres pada Siswa Kelas IX Jurusan IPS dengan Jurusan IPS di SMA N 2 Sukoharjo. Skripsi Universitas Muhamadiyah Surakarta.

Gintulangi, I. \& Prihastuti. 2014. Hubungan Persepsi Mahasiswa terhadap Harapan Orangtua dalam Penyelesaian Studi S1 dengan Tingkat Stres pada Mahasiswa dalam Mengerjakan Skripsi. Jurnal Psikologi Klinis dan Kesehatan Mental Vol. 03 No. 03

Hanum, L., Kawuryan, F., \& Dhania D.R. 2016. Hubungan antara Harapan Orang Tua dan Keyakinan Diri dengan Stres Akademik Siswa Kelas Unggulan. Makalah pada Seminar Nasional Psikologi "Aktualisasi Potensi Anak Bangsa Menuju Indonesia Emas". Diunduh dari https://www.eprints.umk.ac.id.

Harmaini, \& Hidayat. 2012. Mengapa Kegagalan Menyakitkan? Jurnal Psikologi UIN Sultan Syarif Kasim Riau, 8 (Desember), 90-97.

Hidayah, D. N. 2012. Persepsi mahasiswa tentang harapan orang tua terhadap pendidikan dan ketakutan akan kegagalan. Educational Psychology Journal. $\quad$ EPJ $1(1)$ Dikutip dalam http://journal.unnes.ac.id/sju/index.php/epj

Hurlock, E. B. 2000. Perkembangan Anak, Jilid 1, Edisi keenam. Alih bahasa: Meitasari Tjandrasa. Jakarta: Penerbit Erlangga.

Kartono, K. 1990. Psikologi Anak: Psikologi Perkembangan. Bandung: Mandar Maju.

Munauwaroh. 2012. Hubungan harapan orang tua dengan ketakutan akan kegagalan pada mahasiswa Fakultas Psikologi Universitas Islam Negeri Maulana Malik Ibrahim Malang. Undergraduate thesis, Universitas Islam Negeri Maulana Malik Ibrahim.

Nainggolan, L. 2007. Hubungan Antara Persepsi Terhadap Harapan Orang Tua Dengan Ketakutan Akan Kegagalan Pada Mahasiswa Program Studi Psikologi Universitas Diponegoro Semarang. Skripsi Fakultas Psikologi Undip.

Nelson, K. L., Newman, D. N., McDaniel, J. R. \& Buboltz, W. C. 2013. Gender Differences in Fear of Failure amongst Engineering Students. International Journal of Humanities and Social Science Vol. 3 No. 16 (Special Issue - August 2013).

Olejnik, S.N., \& Holschuh, J.P. 2007. College rules! 2rd Edition How to Study Survive, and Succeed. New York: Ten Speed Press.

Permatasari, D.P., Rahajeng U.W., Fitriani F, \& Kurniawati Y. 2018. Parent's academic expectation dan Konsep Diri Akademik Terhadap Kecemasan 
Menghadapi Ujian Nasional siswa SMA. JIPT: Jurnal Ilmiah Psikologi Terapan, Vol. 06, No.01 Januari 2018. 63-73.

Pudjiastuti, E. 2012. Hubungan Self-efficacy Dengan Perilaku Mencontek Mahasiswa Psikologi. Jurnal Mimbar. Vol XXVIII, No 1: 103-112.

Rondha \& Christianingrum, R. 2013.Faktor-Faktor yang Mempengaruhi Rasa Takut Akan Kegagalan dalam Diri Mahasiswa. Makalah dipresentasikan dalam Seminar Nasional Matematika dan Pendidikan Matematika dengan tema "Penguatan Peran Matematika dan Pendidikan Matematika untuk Indonesia yang Lebih Baik" pada tanggal 9 November 2013 di Jurusan Pendidikan Matematika FMIPA UNY. Diunduh dari www.http://eprints.uny.ac.id.

Santrock, J. W. 2008. Psikologi Pendidikan. Jakarta: Prenada Media Group.

Sasikala, S, dan Karunandhi, S. (2011). Development and Validation of Perceptiion of Parental Expectation Inventory. International JournalVol.37, No 1, 114- 124. Indian Academi of Applied Psychology.

Schunk, D.H. 2012. Learning Theories an Educational Perspective. Boston: Publishing as Allyn \& Bacon 501.

Supriyono, A. 2009. Penyelenggaraan Kelas Unggulan di SMA Negeri 2 Ngawi. Tesis. Teknologi Pendidikan. Universitas Sebelas Maret.

Wennberg, K., Pathak, S., \& Autio, E. 2013. How culture moulds the effects of self-efficacy and fear of failure on entrepreneurship. Entrepreneurship and Regional Development, 25(9-10), 756-780. https://doi.org/10.1080/08985626.2013.862975.

Winkel, W. S. 1996. Psikologi Pengajaran Edisi Revisi. Jakarta: PT Grasindo.

Winkel, W. S. 2002. Psikologi Pengajaran. Media Abadi: Yogyakarta.

Y1lmaz, H. 2018. Fear of Success and Life Satisfaction in terms of Self-efficacy. Universal Journal of Educational Research 6(6):1278-1285.DOI: 10.13189/ujer.2018.060619. 